\title{
Evaluation of coronary microleakage in temporary restorative materials used in endodontics
}

\author{
Avaliação da microinfilltração coronária em materiais restauradores temporários usados em \\ endodontia
}

Evaluación de la microfiltración coronaria en materiales restauradores temporales utilizados en endodoncia

\author{
Mácio Emílio Caldeira da Silva \\ ORCID: https://orcid.org/0000-0003-1180-2634 \\ Departamento Municipal de Saúde de Machacalis, Brasil \\ E-mail: maciocs@yahoo.com.br \\ Dilceu Silveira Tolentino Júnior \\ ORCID: https://orcid.org/0000-0003-2435-7576 \\ Universidade Federal dos Vales do Jequitinhonha e Mucuri, Brasil \\ E-mail: dilceujunior@bol.com.br
}

\begin{abstract}
In various situations in the day-to-day of the endodontic clinic, the professional is faced with the need to carry out the work in more than one session. Therefore, it is imperative to select the appropriate temporary restorative material, which does not allow marginal percolation and prevents contamination of the root canal system. Microleakage consists of the passage of fluids from one place to another, and in the oral cavity, it can occur towards the inside of the tooth via the material-tooth interface, taking microorganisms, toxins and chemical substances into the root canal, which would promote the treatment failure. For this, it is necessary to maintain the aseptic chain, through chemical-mechanical preparation and, if there is a need to use a temporary restorative material to seal the endodontic access cavity, it should act as a real barrier to marginal infiltrations. Temporary restorative materials are used in Endodontics to ensure efficient sealing between treatment sessions, as well as after the end of treatment, until the tooth is definitively restored. Several researches are carried out in search of an ideal restorative material. Various materials have been the subject of research and investigation. However, it is essential to perform a temporary restoration in endodontic procedures of multiple consultations, preventing contamination of the root canal system. This article consists of a literature review that addresses the relationship between coronary microleakage and the performance of temporary restorative materials, widely used between endodontic treatment sessions.
\end{abstract}

Keywords: Coronary microleakage; Temporary restorative materials; Endodontics.

\section{Resumo}

Em várias situações do dia-a-dia da clínica endodôntica, o profissional depara-se com a necessidade de realizar o trabalho em mais de uma sessão. Portanto, é imperioso selecionar o material restaurador temporário adequado, que não permita a percolação marginal e previna a contaminação do sistema de canais radiculares. A microinfiltração consiste na passagem de fluídos de um local para outro, sendo que na cavidade oral, pode ocorrer rumo ao interior do dente via interface material-dente, levando microorganismos, toxinas e substâncias químicas para o interior do canal radicular, o que promoveria o insucesso do tratamento. Para isso, faz-se necessária a manutenção da cadeia asséptica, através do preparo químico-mecânico e, se houver a necessidade da utilização de um material restaurador temporário para selar a cavidade de acesso endodôntico, este deverá atuar como real barreira às infiltrações marginais. Os materiais restauradores temporários são utilizados em Endodontia para garantir um eficiente selamento entre as sessões do tratamento, bem como após o término do tratamento, até que o dente venha a ser restaurado definitivamente. Diversas pesquisas são realizadas em busca de um material restaurador ideal. Vários materiais têm sido objeto de pesquisas e investigações. No entanto, é imprescindível a realização de uma restauração temporária em procedimentos endodônticos de consultas múltiplas, impedindo a contaminação do sistema de canais radiculares. Este artigo consiste em uma revisão da literatura que aborda a relação entre microinfiltração coronária e a performance de materiais restauradores temporários, amplamente utilizados entre sessões de tratamento endodôntico.

Palavras-chave: Microinfiltração coronária; Materiais restauradores temporários; Endodontia. 


\section{Resumen}

En diversas situaciones del día a día de la clínica de endodoncia, el profesional se enfrenta a la necesidad de realizar el trabajo en más de una sesión. Por lo tanto, es imperativo seleccionar el material de restauración temporal apropiado, que no permita la percolación marginal y evite la contaminación del sistema del conducto radicular. La microfiltración consiste en el paso de fluidos de un lugar a otro, y en la cavidad bucal, puede ocurrir hacia el interior del diente a través de la interfase material-diente, llevando microorganismos, toxinas y sustancias químicas al conducto radicular, lo que promovería el fracaso del tratamiento. Para ello, es necesario mantener la cadena aséptica, mediante preparación químico-mecánica $\mathrm{y}$, si es necesario utilizar un material restaurador temporal para sellar la cavidad de acceso endodóntico, debe actuar como una barrera real a las infiltraciones marginales. Los materiales de restauración temporal se utilizan en endodoncia para asegurar un sellado eficiente entre sesiones de tratamiento, así como después del final del tratamiento, hasta que el diente esté definitivamente restaurado. Se llevan a cabo varias investigaciones en busca de un material de restauración ideal. Varios materiales han sido objeto de investigación e investigación. Sin embargo, es fundamental realizar una restauración temporal en procedimientos de endodoncia de múltiples consultas, evitando la contaminación del sistema de conductos radiculares. Este artículo consiste en una revisión de la literatura que aborda la relación entre la microfiltración coronaria y el rendimiento de los materiales restauradores temporales, ampliamente utilizados entre las sesiones de tratamiento endodóntico.

Palabras clave: Microfiltración coronaria; Materiales de restauración temporales; Endodoncia.

\section{Introduction}

The purpose of endodontic therapy is to perform microbial control, providing the body with conditions for biological healing through apical sealing and healing of periapical tissues. Therefore, all stages of endodontic and prosthetic restoration must be carefully conducted, independently, aiming at the success and restoration of the health of the dental element.

Barbosa et al. (2003) stated that the success of endodontic treatment, among several factors, also depends on a perfect sealing of the root canal. An imperfect seal would allow bacteria to pass through the filling. Almost all of the works that analyzed the sealing efficiency of the canal filling were done apically. However, some authors became concerned with the analysis of their coronary sealing (Swanson and Madison, 1987; Madison et al., 1987; Madison and Wilcox, 1988; Torabinejad et al., 1990; Magura et al., 1991; Jacquot et al., 1996; Balto, 2002). The referred studies, employing varied methodologies, verified the performance of several techniques and materials in face of the risk situation: exposure of the filling cement in the oral environment. Invariably, they verified the occurrence, to a greater or lesser degree, of coronary infiltration (Zucco, 2001).

Microleakage consists of passing fluids from one place to another, and in the oral cavity, it can occur towards the inside of the tooth via the material-tooth interface, taking microorganisms, toxins, and chemicals into the root canal, which would promote treatment failure (Shinohara et al., 2004). The exposure of the endodontic access cavity to oral fluids allows bacterial penetration towards the periapical tissues, often promoting treatment failure (Saunders, Saunders, 1994). The concern to contain these occurrences is reflected in the studies in the search for temporary materials that provide adequate coronary sealing (Ghisi and Pacheco, 2002).

In numerous day-to-day situations, the endodontist is faced with the need to perform endodontic treatment in more than one session. Therefore, it is essential to choose the ideal temporary restorative material, which does not allow marginal percolation and prevents contamination of the root canal system (Carvalho et al., 2003).

Grossman (1939 apud Pecora et al., 2002) established some basic requirements that a provisional restorative cement should have, such as: be easy to manipulate and insert into the oral cavity, have resistance to compression and abrasion, do not suffer solubility or change dimensional, not disintegrate in the oral environment and promote marginal sealing.

Several studies carried out in recent years have sought to investigate the influence of the properties of temporary restorative materials, traditionally used in dental clinic, on the quality of the coronary seal obtained by the temporary restoration of the endodontic access cavity (Silveira et al., 2005; Travassos and Dias, 2005; Reiss-Araújo et al., 2006; Fachin et al., 2007 and Seixas et al., 2008). Ghisi \& Pacheco (2002) mentioned that the diversity of commercial brands presented for this 
purpose encouraged the authors to look for a material that would prevent coronary microleakage, without, however, obtaining concordant results.

Given conflicting and inconclusive results, the present study aims to conduct a literature review on coronary microleakage, associating it with the sealing ability of four types of temporary cement, used between sessions and after endodontic treatment: cement-based on the oxide of zinc and eugenol (MRI); glass ionomer cement; composite resin and coltosol.

The purpose of this study was to systematize the information according to scientific evidence available in the literature on coronary microleakage and to compare the occurrence of infiltration, in the crown-apex sense, of some temporary restorative materials used in endodontics: cement-based on zinc oxide and eugenol (MRI), Glass Ionomer Cement, Composite Resin and Coltosol, focusing on the importance of sealing the endodontic access cavity, as well as subsidizing the clinician for the proper choice of material to be used between sessions and after endodontic therapy.

\section{Methodology}

This study was a descriptive, qualitative, bibliographic type research, based on a narrative-type bibliographic review (Lacerda \& Costenaro, 2017), carried out in February 2021, in which a selection of scientific articles, monographs, master's theses, and dissertations in Portuguese and English, available from the databases: PubMed, LILACS, and SCIELO. In this sense, the keywords used for research on the platforms were: coronary microleakage, temporary restorative materials, and endodontics.

This type of research stands out for the requirement of the same standards of rigor, clarity, and replication used in primary studies, in addition to constituting the broadest methodological approach referring to literature reviews.

Studies were discarded that did not present the summary and did not address the subject under study, as well as opinionated articles that were not supported by research data or that were not supported by systematic data collection.

\section{Literature Review}

The objective of endodontic therapy, by controlling the cause of the pulp lesion, is to provide the body with conditions for biological healing. Therefore, all stages must be carefully and carefully conducted, since their interdependence requires the same level of rigor in their execution (Zucco, 2001).

Endodontic treatment depends on the chemical-mechanical preparation and filing of the root canal system. The effective sealing of the root canal aims to prevent the formation of exudate, to prevent reinfection by microorganisms that may have remained, and to favor the biological healing process of periapical tissues (De Deus, 1992).

Thus, the filling of root canals has a biological action by promoting the repair of periapical tissues and direct and indirect antimicrobial action. The direct action is on the microorganisms remaining in the chemical-mechanical preparation due to the antiseptic substances in the endodontic cement. The indirect action depends on its ability to physically fill the root canal, avoiding empty spaces that could favor the proliferation of these microorganisms. Another indirect antimicrobial action is the ability of the filling material to prevent the entry of fluids that, in addition to carrying microorganisms, can provide substrate for the proliferation of those that resist the chemical and mechanical effects of therapy. Thus, microorganisms could proliferate in the spaces left inside the filled root canal, constituting the predisposing factor to the installation or perpetuation of the periapical lesion (Zucco, 2001).

Therefore, the sealing produced by the filling cement, as well as by the temporary cement used between the treatment sessions, must be able to resist infiltration (Zucco, 2001; Barbosa et al., 2003; Carvalho et al., 2003; Shinohara et al., 2004). 
According to Jacquot et al. (1996), Balto (2002), Galvan et al. (2002), and Pecora et al. (2002), infiltration or microleakage consists of the movement of fluids and/or microorganisms, from the periapical region, lateral periodontium, or oral medium, into the root canal.

The Washington Study, carried out in 1965, cited by Madison (1987), evaluating the successes and failures in Endodontics, suggests as the main cause of endodontic failures, the apical infiltration of exudates into the interior of incompletely filled canals. Approximately $60 \%$ of unsuccessful cases had an incomplete filling of the root canal space. The authors did not relate this reality to the presence of microorganisms. In an antagonistic way, Soares (2002), Haapasalo et al. (2003) and Siqueira Jr and Rôças (2008), when investigating periapical lesions refractory to treatment, observed the microbial presence in all lesions and concluded that the occurrence of anaerobic and facultative bacteria in the lesions guarantees the maintenance of the infectious process and resistance to treatment.

Siqueira Jr \& Rôças (2008) emphasized that the presence, direct and/or indirect, of microbial activity is the basic cause of endodontic failures and lists three situations that favor it. The first is related to the presence of microorganisms lodged on the external surface of the root (in cases of persistent lesions); the second with the presence of these inside the channel system (when they are not affected by the chemical-mechanical preparation); the third with their egress from the oral environment (when the contact of the filling with saliva occurs). Regardless of the situation, microorganisms have the potential to (re) colonize both the channel system and the periapical region.

Soares (2002) states that the repercussion of intracanal infection in the tissues of the dental organ and consequently in the organism has always aroused the curiosity of many researchers and contributed to the understanding of several pathologies of endodontic origin.

Zucco (2001) highlights conditions that make it difficult to obtain the ideal conditions for sanitation, shaping, and sealing in endodontic therapy. Factors inherent to the patient: position of the involved dental element, its access and visibility, its complex root anatomy, and the patient's cooperation. About the professional, there is the level of improvement of the same, the adoption of asepsis and antisepsis measures, and the selection of appropriate techniques and materials. Even when difficulties are overcome, there is still the challenge of maintaining the sanitation conditions achieved during or after therapy. Therefore, obtaining and maintaining the coronary seal assumes an important role in the success of endodontic treatment. Failures in this sense favor the (re) contamination of the canal system - filled or not - to the oral environment. Therefore, the deficiency of the coronary sealing puts at risk the success of the instituted chemical, mechanical and biological therapy.

Allisson et al. (1979 apud Zucco, 2001), were pioneers in emphasizing the importance of coronary infiltration in the prognosis of endodontic therapy, emphasizing that it establishes a direct communication route between the oral environment and the periapical tissues.

Madison et al. (1987) questioned: if apical sealing is a significant factor in the prognosis of endodontic therapy, what role should coronary sealing play in the overall prognosis? These authors argue that the failures in the coronary sealing expose the root canals and/or the obturator material to the oral environment and consequently to its microbiota, a complex population, consisting of several cells distributed in the saliva and other oral ecosystems.

Zucco (2001) points out that this exposure allows the penetration of chemical components of saliva, which constitute a substrate for the remaining microorganisms in the channel system, enabling their growth and development, which increases their potential for aggression. Thus, it is obvious that the possibility of infiltration of salivary fluids to the periapical region is an important factor in assessing the failure of endodontic therapy.

According to Pashley (1990), most materials used in dentistry allow the occurrence of varying degrees of microleakage of bacteria and their products from oral fluids, through dentin. Therefore, understanding the clinical consequences of microleakage requires an analysis of the characteristics of dentin, which, being tubular, is permeable. 
Coronary dentin, located above the pulp horns, is much more permeable than root dentin. In addition, the dentin that is exposed during tooth preparation represents the greatest potential for microleakage.

Swanson and Madison (1987) evaluated coronary microleakage after the period of exposure of the material to the simulated oral fluids. After the teeth were treated endodontically, a cotton swab was introduced into the pulp chamber, the access cavities being sealed with Cavit (figure 1). The teeth remained in an environment of $100 \%$ humidity at $37^{\circ} \mathrm{C}$, for 48 hours, for the cement to set. After that time, the seal was removed and the external surfaces were covered with wax, except for the access opening. The teeth, randomly divided into six groups, were exposed to artificial saliva at different times of 3, 7, 14, 28, and 56 days, except for the control group, and they were immersed in Indian ink for 48 hours. Subsequently, they were decalcified in 5\% nitric acid for $48 \mathrm{~h}$, washed for 4 hours, and dehydrated in 90\% ethyl alcohol for 2 hours and 100\% alcohol for 3 hours; next, they were cleared in methyl salicylate. Infiltration was measured. It was observed that all teeth exposed to saliva showed infiltration soon after the 3rd day, covering $79 \%$ to $85 \%$ of the root.

Moved by the issue of the occurrence of the dissolution of endodontic cement, Madison et al. (1987) compared, in vitro, the occurrence of coronary infiltration with the use of different types of cement. The specimens, after filling the canals, were exposed to artificial saliva for one week, and then immersed in ink and later cleared. The positive control group, filled with only gutta-percha cones, without cement, simulating a poorly filled canal, showed infiltration along the entire length of the canal. The negative control group, filled, with its coronary portion sealed with Cavit and covered with sticky wax, mimicking the seal provided by the coronary restoration, did not show infiltration.

Torabinejad et al. (1990) investigated how long it takes for bacteria from the oral environment to penetrate, via the coronary portion, into root canal filling. They used 45 upper incisors, filled using the lateral condensation technique, which had the coronary portion of the filling placed in contact with Staphylococcus Epidermidis and Proteus Vulgaris. They obtained that it took an average of 48.6 days for Proteus vulgaris to reach the filling material of the apex area, while bacterial penetration with Staphylococcus Epidermidis was more consistent, with an average of 24.1 days for apical infiltration to occur.

In addition to the use of a methodology that uses the dye to check coronary infiltration, Magura et al. (1991) used histological and microbiological assessments. In the referred experiment, 160 extracted teeth were used, of which 150 were filled with cement-based on zinc oxide and eugenol (Roth's), and 10 remained without filling. After one week, 100 teeth had the cervical seal removed, constituting the experimental group, while the remaining 50 teeth remained with the seal, forming the negative control group. The 10 teeth that remained unfilled constituted the positive control group. All teeth were placed in contact with human saliva for 90 days and at each time interval $(2,7,14,28$, and 90 days), 32 teeth were analyzed: 10 teeth in the experimental group were immersed in paint ink and diaphanized; 10 teeth in the experimental group and 10 teeth in the negative control group were evaluated histologically, and two teeth in the positive control group were subjected to microbiological tests. In the study, the results of the analysis of dye penetration revealed the existence of a direct relationship between the time of exposure to saliva and the level of coronary infiltration, and, at three months of exposure, there was complete infiltration of the root canal filling, which was, on average, 9.2 millimeters in length.

However, the results of the histological evaluation of the specimens, in contact with the saliva for ninety days, showed that the mean of infiltration in the negative control group $(6.5 \mathrm{~mm})$, with sealing at the entrance of the channels, was greater than the mean of the experimental group $(4.9 \mathrm{~mm})$, which did not have a coronary steal. The authors justify the inadequate thickness of the temporary sealer. Based on these observations, clinically, infiltration could occur even without direct exposure of the obturator material to the oral environment. When relating the values of the experimental groups, the data obtained with the histological analysis provide lower saliva infiltration values than those achieved by the dye. In the discussion, the authors explain that these results are due to the viscosity of saliva and that the use of dyes, due to their greater penetration, provided higher levels of infiltration than those obtained with histological analysis. Paradoxically, the authors base their conclusions on 
the data provided by the analysis of dye penetration and recommend that filled canals, exposed for three months or more to the oral environment, should be portrayed.

Ray \& Trope (1995) evaluated the relationship between the quality of permanent coronary restoration, root canal filling, and the state of the structures around the root apex, through periapical radiographs, in endodontically treated teeth. To this end, they examined periapical radiographs of patients at Temple University School of Dentistry, Philadelphia. The sample consisted of 1010 teeth with endodontic treatment, which had been definitively restored for at least one year. When relating the quality of endodontic treatment and coronary restoration with periapical health, it was observed that when the canals were well filled and with good restorations, the rate of presence of periapical lesions was $8.6 \%$ and when coronary restorations presented inadequate, this index rose to $56 \%$. In specimens whose channels had flaws, detected radiographically, and were properly restored, the rate of periapical lesions was $32.4 \%$ and when the restoration also had flaws, this rate reached the proportion of $82 \%$. Taken together, these indices signal the fact that the condition of coronary restorations was significantly associated with an increase in the presence of periapical lesions.

The authors highlighted that a very special emphasis should be placed on the quality of coronary restoration, to ensure the results obtained with endodontic therapy. Thus, the dental element must have its coronary restoration performed as soon as possible, avoiding the use of provisional materials for long periods. Endodontic therapy will only be completed after the definitive restoration of the form and function of the treated element. In this sense, its use should be restricted to short periods and selection criteria according to the properties of the material (Zucco, 2001).

Based on this premise, several studies were carried out, with varied methodologies, to test temporary restorative materials in the most diverse combinations, verifying their performance in the situation that simulated the exposure of the filling to the oral environment (Webber et al, 1982; Chohayeb and Bassiouny, 1985; Anderson et al., 1988; Bobots et al., 1989).

Webber et al. (1978) argue that the function of temporary restorative materials in endodontics is twofold: first, that of preventing saliva and microorganisms from entering the root canal, preventing infection or reinfection; second, to prevent medications placed in the pulp chamber from leaving the oral cavity, thus preserving the effectiveness of intra-channel medication and avoiding any chemical abrasion on the oral mucosa. These authors evaluated the necessary thickness of Cavit in cavities with endodontic access, to promote an appropriate seal. Half of the teeth received a cotton swab moistened with camphorated paramonochlorophenol, and the rest was also placed in the pulp chamber, but without medication. This was done to leave a space of less than $5 \mathrm{~mm}$, which was filled with Cavit. The roots were waterproofed with wax, until the cement/enamel junction, and then immersed in $10 \%$ methylene blue dye, at $37^{\circ} \mathrm{C}$ for 48 hours. The teeth were washed, sectioned in the mesiodistal direction and the cotton swab was examined for discoloration of the dye. The infiltration was analyzed, using a compass, in the filling material and the tooth/filling interface, through the penetration of the dye. The results suggested that a thickness of Cavit of $3.5 \mathrm{~mm}$ may prevent the infiltration of the dye.

Tamse et al. (1982) evaluated the sealing ability of Cavident, comparing it with MRI, Kalzinol, Cavit, and Cavit G. The specimens were placed in saline at $37^{\circ} \mathrm{C}$ for three days, and then in methylene blue at $1 \%$ and eosin ya $0.5 \%$ for seven days. Thermocycling was described as follows: two baths were carried out for the dye solutions lasting two minutes, one at $60^{\circ}$ $\mathrm{C}$ and the other, with ice water, being repeated 10 times. Subsequently, the teeth were washed, placed in saline solution for 24 hours at $37 \%$. Then, they were dried and sectioned. They observed that the infiltration through the dentin-restoration interface occurred when the MRI or Kalzinol was used and the infiltration through the material itself was observed in Cavit, Cavit G, and Cavident.

Chohayeb \& Bassiouny (1985) investigated the efficiency of Adaptic and Aurafil composite resins, as a temporary restorative material in Endodontics, about the sealing capacity when compared to other materials: Cavit, zinc oxide and 
eugenol, and zinc phosphate cement. After the root canals were instrumented, a cotton swab was inserted into the pulp chamber, taking care to leave a $2.5 \mathrm{~mm}$ space for placing the restorative material. The waterproofing was performed with nail polish and immersion in methylene blue dye at $4^{\circ} \mathrm{C}$ and $58^{\circ} \mathrm{C}$, lasting 2 minutes, in each bath, 40 times. The best results, regarding the depth and intensity of penetration of the dye in the root canal system, were found with Cavit, which demonstrated a high degree of marginal sealing in the access cavities, followed by resins. Zinc oxide and eugenol and zinc phosphate cement showed high rates of marginal infiltration.

Anderson et al. (1988) evaluated coronary microleakage in teeth treated endodontically and restored with Cavit, MRI, and TERM (Temporary Endodontic Restorative Material). Microleakage was measured using a fluid filtration technique, which does not physically displace the cavity restoration, at time intervals of 1 hour, 24 hours, and 7 days. The teeth were thermocycled at 60 cycles in alternating baths of $4^{\circ} \mathrm{C}+2^{\circ} \mathrm{C}$ and $56^{\circ} \mathrm{C}+2^{\circ} \mathrm{C}$, remaining 2 minutes each; microleakage was measured again. After the 7th day and thermal stress, they observed that Cavit and TERM demonstrated effective sealing, while the MRI showed significant infiltration.

Bobots et al. (1989) carried out a study to quantify in time intervals, the sealing ability of Cavit, Cavit G, TERM, Glass Ionomer cement FUJI II, zinc phosphate cement, polycarboxylate cement, and MRI. After preparing the access cavities, cotton swabs were placed in the pulp chamber, leaving a space of $4 \mathrm{~mm}$ for placing the restorative material. Soon after, the teeth were immersed in saline and incubated at $37^{\circ} \mathrm{C}$. A buffered sulfate solution containing $2 \%$ fluorescine dye was introduced into the pulp chamber. The results indicated that Cavit, Cavit G, TERM, and Glass Ionomer cement provided effective sealing until the 8th week of the test, while MRI and polycarboxylate cement showed less efficiency in sealing cavities.

Lee et al. (1993) compared the sealing of three materials: Caviton, Cavit, and IRM in two powder-liquid proportions $(6 \mathrm{~g} / \mathrm{ml}$ and $2 \mathrm{~g} / \mathrm{ml})$. Endodontic access was standardized on 140 human molars, extracted, without restorations, and without caries lesions. After the removal of pulp tissues, the chambers were dried and filled with a piece of cotton, so that the provisional restorative material could occupy $4 \mathrm{~mm}$ in depth. The teeth were randomly divided into 6 groups: 4 experimental and 2 controls (positive and negative). Each experimental group had 25 teeth, being a group I sealed with Caviton, II with Cavit, III with MRI (powder - liquid ratio $6 \mathrm{~g} / \mathrm{ml}$ ), and IV with MRI (powder - liquid ratio $2 \mathrm{~g} / \mathrm{ml}$ ). The control groups had 20 teeth each, and in the positive, no sealing material was inserted in the cavity, and in the negative, the crowns remained intact. The materials were handled according to the manufacturers' recommendations and microleakage was observed, using the basic fuchsin dye after thermocycling from $5^{\circ} \mathrm{C}$ to $55^{\circ} \mathrm{C}$ for 30 seconds each. The data obtained allowed us to conclude that Caviton promoted better sealing than Cavit, and that it sealed better than MRI, with a significant statistical difference.

The microleakage of several provisional restorative materials was also the target of studies by Carman \& Wallace (1994). These authors used 96 human molars, dividing them into 6 groups of 15 teeth with 3 positive and 3 negative controls. The 6 experimental groups were based on the use of the material to restore the pulp chamber and the remaining space of the canal: 1-gutta-percha with cement; 2-amalgam; 3-IRM; 4-photopolymerizable posterior composite; 5-chemically activated paste; 6-Light-curing glass ionomer. After placing the material, the teeth were thermocycled between $5^{\circ} \mathrm{C}$ and $60^{\circ} \mathrm{C}$ for 100 cycles at 30-second intervals. Then, the teeth were covered with sticky wax, in such a way that only the restorative material was exposed.

The positive control was similarly covered with wax, but without the insertion of the restorative material; the negative control was completely covered with wax, using a cotton ball in the pulp chamber. The teeth were immersed in a $2 \%$ methylene blue solution for 7 days. The results showed that the negative control showed no infiltration, one of the positive control showed complete infiltration and two others showed infiltration of 7 and $6.5 \mathrm{~mm}$. Among the materials tested, the lightcuring glass ionomer cement and amalgam provided the best result. There was no significant difference between the values of 
infiltration of the chemo-polymerized paste, the photopolymerizable composite, and the MRI, with these having a greater sealing capacity than gutta-percha with cement.

Kazemi et al. (1994) evaluated the marginal stability and impermeability of Tempit (temporary restorative endodontic material) and compared the results with Cavit and MRI. Initially, the endodontic access cavities were restored with the tested materials, exposed to the methylene blue solution, and subjected to 350 thermal cycles, remaining in the solution for 5 days, then being sectioned. The penetration and diffusion of the dye solution were measured around the margins and in the body of the materials. Then, a special study was carried out in standardized glass tubes to better evaluate the marginal penetration and in the material body. They concluded that Cavit exhibited the best sealing ability in the two stages of the study.

In contrast to most of the results described in the literature, the studies by Jacquot et al. (1996) quantified the sealing ability of four temporary filling materials for 9 days, using a new electrochemical technique. Fifty-two extracted premolars were selected and prepared for measurements. They were divided into four groups of 12 teeth each, two specimens were used for the positive control (empty cavity) and two for negative control (intact crown). After endodontic access, one group was restored with MRI, another group with Cavit, the third group with Cavit W, and the last group with Cavit G.

The sealing was measured right after making the provisional restoration (time zero) and, after 1, 2, 3, 4, 7, and 9 days. The sealing of the IRM decreased until the second day. For the group that was restored with Cavit, the decrease developed until the ninth day. For the Cavit W group, the decrease stabilized on the seventh day. Finally, in the Cavit G group, sealing decreased until the fourth day. Until the third day there was no significant difference between the groups MRI, Cavit, and Cavit W. During the whole experiment, the Cavit G group had a smaller seal than the other groups and the resistance of the positive and negative controls remained constant. The authors concluded that the MRI had a greater sealing capacity than Cavit and its different formulations.

Pisano et al. (1998) evaluated the sealing capacity of Cavit, MRI, and Super-EBA as restorative materials for the entrance orifice of the channels, after removing $3.5 \mathrm{~mm}$ of the root canal filling, to prevent the microleakage of human saliva and its components, in the absence of coronary restoration. The specimens were exposed to the penetration of saliva in a culture medium. The bacterial penetration was detected by the increase in the turbidity of the medium, corresponding to the bacterial growth. After 90 days, the results showed that the infiltration occurred in 15\% of the holes sealed with Cavit and 35\% of the holes sealed with MRI and Super - EBA. They concluded that, since root canal filling is exposed to the oral microbiota, endodontic therapy is compromised.

Gekelman et al. (1999) stated that the recontamination of prepared root canals can occur between treatment sessions in clinical circumstances, such as fracture and percolation or loss of provisional restoration. These authors evaluated the properties of various provisional restoration materials, using the in vitro method of dye infiltration after thermocycling: MRI (group I); gutta-percha and Cimpat (Group II); Cimpat (group III); Cimpat and MRI (group IV). Forty upper and lower human molars were randomly divided into four groups of ten teeth each and restored with the aforementioned materials. All specimens were thermocycled, 150 cycles of two minutes each were performed and then waterproofed by the application of two layers of ethyl cyanocrylate. The teeth were immersed in a $0.5 \%$ methylene blue dye solution and kept in an oven at $37^{\circ} \mathrm{C}$ for 7 days. Then, plaster was added to the occlusal surface.

Sequentially, they were longitudinally worn from the buccal surface towards the lingual face, until the complete exposure of the sealed area. The data were processed and the average microleakage was obtained for each group: $95.5 \%$ for group I (MRI); $34.10 \%$ for group II (gutta-percha and Cimpat); $25.34 \%$ for group III (Cimpat) and 50.11\% for group IV (Cimpat and IRM). Such measurements of the level of linear infiltration of dye in each specimen allow us to conclude that the MRI was less effective in preventing microleakage and that Cimpat promoted the best seal. 
Starting from the premise that the success of endodontic treatment depends on an efficient coronary sealing, Sauáia (2000) argues that during endodontic therapy it is important to create a perfect seal in the access of the coronary cavity to prevent microleakage and the ingress of fluids and microorganisms in the root canals. The referred author proposed in her research, to contribute to the equation of this subject, aiming at the improvement of the exercise of the endodontic clinic. Her work aimed to evaluate in vitro the capacity of coronary sealing of four materials placed in the pulp chamber, immediately after filling the root canals. 100 freshly extracted human molars were used, randomly divided into five experimental groups with 20 teeth each, as a positive control group. After the final cleaning of the coronary chamber, the Flow Resin Composite, Z100 Composite Resin, Cavit, and Vitremer sealing materials were inserted. Then, the teeth were subjected to 600 thermal cycles and then submerged in Indian ink for 5 days. The sample was decalcified, dehydrated and cleared, and then examined using a stereoscopic magnifying glass. Infiltration levels were coded and examined by three examiners at different times. Statistical analysis revealed that Cavit and Resin Z100 sealed better, although there was no significant difference between the materials. Flow Composite Resin showed medium infiltration behavior and Vitremer presented the worst seal.

Liberman et al. (2001) compared MRI and Cavidentin for coronary sealing but considering an important variable: occlusal strength. Regarding coronary sealing, both had a similar quality. However, when subjected to repetitive chewing over $4 \mathrm{~kg}$, the MRI was superior, as it maintained a reasonable seal and Cavidentin deteriorated, losing its sealing capacity. Fiftyfour caries-free molars were randomly selected and divided into three groups: sixteen specimens were sealed with MRI; sixteen with Cavidentin; sixteen with amalgam and the rest served as positive and negative controls. The results suggested that Cavidentin can be used in situations that do not require occlusal force, while MRI should be indicated in cases subject to the greatest masticatory force.

The microbial infiltration of the MRI, Cavit, and Dyract, when used as temporary restorative materials after root canal treatment, was the object of study by Balto (2002). The degree of coronary infiltration was assessed using a microbiological marker consisting of Streptococcus Faecalis and Candida Albicans. For each of the two organisms, a set of 15 premolars was prepared chemomechanically and filled with thermoplasticized gutta-percha. All teeth were instrumented and filled in the same way by the same operator and randomly divided into 3 groups of 10 teeth each. Group 1 was filled with Cavit and group 2 with MRI. Group 3 teeth received a thick $3.5 \mathrm{~mm}$ layer of Dyract, while group 4 consisted of 8 teeth used as positive and negative controls (4 teeth each). The results indicated that Dyract and Cavit provide a better coronary seal than MRI.

Similar research was carried out by Uranga et al. (1999), who compared the sealing ability of temporary restorative materials (Cavit and Fermit) and permanent restorative materials (Dyract and Tetric) and found that the definitive materials were more effective than the provisional materials in preventing coronary microleakage.

Following this same line of investigation, Ghisi \& Pacheco (2002) evaluated, in vitro, the infiltration of dye in the coronary portion of three temporary restorative materials: MRI, Cimpat Blanc, and Bioplic (figure 3). Forty-five healthy human first molars, extracted for therapeutic indication, were selected for this study. After coronary access, the teeth were divided into 3 groups, according to the type of temporary material used to restore the access cavity:

Group 1 (IRM); Group 2 (Cimpat Blanc); Group 3 (Bioplic). Then, the teeth were waterproofed, subjected to thermal cycling, immersed in $0.5 \%$ basic fuchsin for $24 \mathrm{~h}$, and sectioned in the mesiodistal direction, obtaining 4 faces for evaluation. The results showed that MRI showed the highest coronary microleakage, while Cimpat Blanc and Bioplic demonstrated similar sealing capacity, with a statistically superior behavior to MRI.

Using similar methodological resources, Carvalho et al. (2003) investigated the ability to seal temporary cement, used between sessions in endodontic treatment, against the action of the bacterium Enterococcus Faecalis. 26 lower premolar teeth were selected, divided into 3 groups. Group 1 received double sealing, with Glass Ionomer cement and zinc oxide, and eugenol. Group 2: sealing with Cimpat and Glass Ionomer. And Group 3: sealing with Cimpat and zinc oxide and eugenol. 
One of the samples was kept untreated for negative control. Another sample did not receive a seal, leaving the coronary opening exposed, for positive control. All teeth were adapted to silicone devices and placed in glass containers containing $50 \mathrm{ml}$ of sterile culture medium broth (BHI), with the roots inside the container and the crowns inside the silicone devices. The observation was carried out daily for 15 days and, after this period, the invasion of the microorganism was noted in all groups, but there were significant differences. The samples belonging to group 3 (sealing performed with Cimpat and zinc oxide and eugenol) obtained the best results, as only $25 \%$ of the specimens suffered percolation of bacteria. In group 2 (sealing with Cimpat and Glass Ionomer), the infiltration occurred in 37.5\% of the teeth. In group 1 (sealing with Glass Ionomer and zinc oxide and eugenol), 50\% of the specimens underwent infiltration. Therefore, none of the tested cement provided $100 \%$ of the seal between the external environment and the interior of the channel.

Mattos et al. (2003) used 30 single-root human premolars and subdivided them into three groups, according to the provisional restorative material: Group 1 received Citodur cement of the Hard type; Group 2 received Bioplic and Group 3 was restored with Tempit $\mathrm{L} / \mathrm{C}$. The teeth were subjected to thermal cycling $\left(150\right.$ cycles at $5+2{ }^{\circ} \mathrm{C}$ and $\left.60+2{ }^{\circ} \mathrm{C}\right)$, immersed in $0.5 \%$ methylene blue dye, and subjected to vacuum for 1 hour. Then, they were worn longitudinally and photographed superimposed on a millimeter ruler, in which the linear infiltration of the dye was measured. Tempit L / C presented the best result, followed by Citodur (Hard) and Bioplic, which was considered inefficient as a temporary restorative material.

Shinohara et al. (2004) studied in vitro the coronary microleakage of four temporary sealing materials used in Endodontics: MRI, Bioplic, Dentalville, and Vitremer. Forty-two human molar teeth were divided into six groups of seven teeth. Inside each pulp chamber, three cotton balls impregnated with $1 \%$ dimethylglioxima alcoholic solution, and the tested sealing materials were placed. Then, the teeth were waterproofed, immersed in a $5 \%$ nickel sulfate solution, subjected to thermal cycling $\left(5^{\circ} \mathrm{C}, 37^{\circ} \mathrm{C}\right.$ and $\left.55^{\circ} \mathrm{C}\right)$ for seven days, and sectioned in the mesiodistal direction. The results indicated that the MRI had the highest coronary microleakage, followed by Vitremer and Dentalville. Bioplic showed a low infiltration value.

Marques et al. (2005) evaluated the sealing capacity of four temporary restorative materials: photopolymerizable composite resin, glass ionomer cement, Coltosol (figure 4), and Bioplic. Standardized coronary access cavities (class II) were performed on forty-two extracted upper premolar teeth obtained from the Human Teeth Bank of the Faculty of Dentistry at UFPE. The specimens were temporarily restored with the studied materials, thermocycled at 125 cycles from $5^{\circ} \mathrm{C}$ to $55^{\circ} \mathrm{C}$, with an immersion time of 15 seconds. All materials tested showed coronary infiltration, and Coltosol and Bioplic showed homogeneous behavior about the degree of infiltration and were considered more effective than composite resin and Glass Ionomer when used as a temporary restorative material.

According to Gekelman et al. (1999); Ramos \& Galan Jr (2004); Silveira et al. (2005); Seixas et al. (2008), the provisional sealing during the endodontic treatment is performed to maintain the disinfection obtained during the biomechanical preparation, being, therefore, an essential element to achieve the success of the endodontic therapy. Ramos \& Galan Jr (2004) compared the performance of four temporary sealing materials after endodontic treatment: gutta-percha, Glass Ionomer, Bioplic and zinc oxide, and eugenol. Twenty uniradicular teeth were used and, after inserting the materials in the cavities, they were stored separately in distilled water for 7 days. On the seventh day, the groups were immersed in Rhodamine-B dye $0.5 \%$ in distilled water for another 24 hours. After this period, the specimens were washed in running water, dried, and sectioned in the vestibulo-lingual direction. The samples were evaluated by two independent examiners and showed different rates of marginal infiltration: Glass Ionomer (grade $0 \rightarrow$ no infiltration) Bioplic and zinc oxide and eugenol (grade 1 $\rightarrow$ infiltration only at the enamel interface); gutta-percha (grade $3 \rightarrow$ infiltration beyond the enamel-dentin junction).

From this same perspective - to study the microleakage of temporary sealers between endodontic therapy sessions Silveira et al. (2005) proposed to evaluate in vitro the marginal infiltration of two sealing materials: MRI and Coltosol. Ninety- 
six uniradicular premolars were selected and divided into eight groups of 12 specimens each (one specimen for the positive control and one specimen for the negative control). After conventional coronary access, the teeth were instrumented using the Oscillatory Movement technique. In the negative control, both materials were inserted in the crowns of the teeth and, immediately afterward, completely waterproofed; in the positive control, only the root was waterproofed, and no temporary sealing material was placed in the coronary opening. The root conduits of the samples were dried with absorbent paper cones impregnated with $1 \%$ dimethylglioxima and a cotton ball with the same substance was compacted in the pulp chamber.

The teeth restored with the tested materials were immersed in a 5\% nickel sulfate solution at intervals of three, seven, fourteen, and twenty-eight days. After being subjected to thermal cycling $\left(5^{\circ} \mathrm{C}, 37^{\circ} \mathrm{C}\right.$ and $\left.55^{\circ} \mathrm{C}\right)$, they were cleaved in the mesiodistal direction and the results were observed by the red color (formation of the Ni-dimethylglioxima complex) in the cotton ball, measured in a magnifying glass stereomicroscopic Wild M8 with a six-fold magnification. They concluded that the MRI showed worse results than Coltosol in the intervals of three, seven, and fourteen days. However, with 28 days of posttreatment, there was no significant difference between the restorative materials in terms of the depth of infiltration. The two provisional sealing materials tested allowed infiltration of the restorative material / dental tissue interface in the four-time intervals.

Using the same study model, Travassos \& Dias (2005) aimed to evaluate the ability to prevent coronary microleakage through the penetration of $2 \%$ methylene blue dye from three temporary sealant materials used in endodontic practice: zinc oxide and eugenol, Bioplic and Vitro Fill, a glass ionomer cement. The coronary opening was performed on 32 teeth, third human lower molars, of which 2 served as positive and negative control groups. The teeth were subjected to preparation with conical trunk drills at the entrance of the root canal, until the beginning of the middle third and later filled with small portions of gutta-percha. A dry cotton ball was introduced into the pulp chamber so that the temporary restorations were approximately the same length (5 to $6 \mathrm{~mm}$ ). Then, each group received the respective pre-selected provisional seal, which was properly manipulated, condensed, and adapted in the cavity. Group I received zinc oxide and eugenol as a temporary restorative material; group II received Bioplic, which was light-cured for 40 seconds, and group III, Vitro Fill Glass Ionomer.

After the cavities were filled with the provisional materials, the teeth were waterproofed with three layers of ethyl cyanoacrylate, to seal possible cracks, cracks, lateral channels, and accessories that could compromise the results. After waterproofing, the specimens were immersed in a $2 \%$ methylene blue solution for 48 hours, washed in running water for 24 hours, dried for 12 hours, and then sectioned in the longitudinal direction to assess the degree of coronary infiltration through scores variables from 0 to 4 . The results showed that Bioplic was the material with the best marginal sealing capacity, followed by Vitro Fill. Zinc oxide and eugenol determined the worst results.

A few years ago, the most recommended temporary sealing materials between sessions of endodontic treatment were zinc oxide and eugenol, Coltosol, Cimpat. Concerned about infiltration and coronary microbial contamination, researchers conducted studies to analyze the real reliability of these materials in sealing the pulp cavity between possible sessions of endodontic therapy, since coronary sealing is paramount (Reiss - Araújo et al., 2006).

The aforementioned authors studied the antimicrobial activity of two temporary sealing materials Vitro Fill and Vitro Molar against the mixed culture of Pseudomonas aeruginous and Enterococcus faecalis, as well as against each of the bacteria alone. The cultures were inoculated on the surface of the Müller-Hinton medium previously distributed in Petri dishes. As a positive control of the experiment, two plates sown in Müller-Hinton culture medium from each tested culture were used. As a negative control, two Petri dishes were used with the same culture medium, however, there was no bacterial sowing in these.

For each of the temporary sealers, two specimens per plate were prepared. The materials were handled according to the manufacturer's instructions and, then, with the aid of an amalgam holder, specimens of standardized diameter and length in 3 and $5 \mathrm{~mm}$ were made respectively. It was waited for the material to become trapped and in each hemiarch of the plate, on the 
surface of the inoculated medium, two specimens of each material were placed at the points previously marked. Then, all plates were incubated in a biological oven at $37^{\circ} \mathrm{C}$. Two readings were made for each specimen; the first with $24 \mathrm{~h}$ and the second after 48h. Bacterial inhibition halos were observed around the specimens of Vitro Molar, which varied from 0.7 to 1.0 $\mathrm{cm}$ in the presence of the isolated Pseudomonas aeruginosa culture; no inhibition halos were found around the other test specimens tested, both for Enterococcus faecalis and mixed cultures. The provisional coronary sealer Vitro Molar was the only one that showed antimicrobial activity, which occurred before the pure culture of Pseudomonas aeruginosa. No material exerted antimicrobial activity against the pure culture of Enterococcus faecalis and the mixed culture under test.

Fachin et al. (2007) compared in vitro the sealing ability of the following temporary restorative materials: Bioplic, Cavit, IRM, and Tempore. These authors concluded that Bioplic showed superior performance among the other materials, to lower levels of infiltration, despite still allowing infiltration. The weakest performance in terms of marginal sealing was presented by the IRM, considered inferior to all the provisional restorers used in such research, showing no difference with the gutta-percha (control group). The results found in that study become more consistent when compared with the findings of Shinohara et al. (2004) and Marques et al. (2005).

Seixas et al. (2008) evaluated ex vivo the coronary marginal microleakage of several provisional restorers. For this, forty-six canines were used. After performing the endodontic access and chemical-mechanical preparation, they introduced an absorbent paper cone into the root canal and a cotton swab impregnated with $1 \%$ dimethylglioxima alcoholic solution in the pulp chamber. The specimens were divided into four groups, containing ten elements each, according to the restorative material: G1-Vidrion R; G2-Cavit W; G3-Villevie; G4-Bioplic; positive control - received no material (03 specimens); negative-restored control with Cavit W and waterproofed by two layers of cosmetic enamel (03 specimens). Subsequently, all teeth were subjected to thermal cycling for 72 hours. Then, they were sectioned longitudinally and placed in Petri dishes containing gauze soaked with drops of ammonium hydroxide, to fix the reddish color of the formed Ni-dimethylglioxima complex. The data showed that the provisional restorative materials Bioplic and Villevie suffered less infiltration, followed by Cavit W and, finally, Vidrion R. It was concluded that, although the restorers Bioplic and Villevie had the lowest infiltration rate, no material prevented marginal coronary infiltration.

Swansson \& Madison (1987); Madison et al. (1987); Madison \& Wilcox (1988), consider apical infiltration as the most common cause of failure of endodontic therapy, due to the inadequate sealing of the root canal system with consequent exudate penetration. However, these authors call attention to another major reason for the clinical failure produced through coronary microleakage, due to the lack of sealing of the access cavity or microleakage through temporary material or even the permanent restorative, resulting in contamination of the root canal.

The correct filling of the root canal and the improved restoration of the dental element prevent bacterial proliferation and recontamination. Following this principle, the need for the use of a good temporary sealer between treatment sessions is indisputable (Salazar - Silva et al. 2004). These authors argue that the greatest concern in endodontic therapy is based on combating microorganisms belonging to the endodontic flora. Special importance has been given to coronary restorations, whether temporary or permanent, as their improper use can contribute to the failure of endodontic treatment.

Oliveira (2005) states that the purpose of the provisional restorative materials would be to protect the dentin or the exposed pulp cavity from the aggressors, coming from the oral cavity, or to prevent the medications placed inside the canal from leaving the oral environment, thus avoiding the fluid exchange between the oral cavity and the root canal.

Therefore, there seems to be no longer any doubt that the success of endodontic treatment depends on efficient coronary sealing; its deficiency can prevent the maintenance of a favorable biological environment for the restoration and maintenance of normal apical tissues (Uranga et al, 1999; Sauáia, 2000; Uçtash and Tinaz, 2000; Barthel et al., 2001; Wolaneck et al., 2001; Wells et al., 2002; Hizatugu, 2002; Tewari and Tewari, 2002; Heleno, 2004). 


\section{Results and Discussion}

The main requirement for the success of endodontic therapy, in addition to respecting the specific technique of each phase and maintaining the aseptic chain, is to promote the hermetic and three-dimensional sealing of the root canal system. The success of endodontic treatment is related to the level of sanitation of the canal system, the filling capacity to maintain it, the adequate rehabilitation of the dental element, and the reaction capacity of the organism (Zucco, 2001).

However, based on the advancement of microbiological techniques, studies such as those by Soares (2002), Haapasalo et al. (2003), and Siqueira Jr and Rôças (2008) have verified the constant microbial presence inside the filled canals and/or in the periapical region of teeth involved in endodontic failures. Zucco (2001) recognizes that one of the possibilities for the origin of such contamination is related to the penetration of microorganisms that constitute oral microbiota, which, permeating the filling material, reach the periapical tissues, installing and/or maintaining a periapical lesion, configuring themselves whether, thus, coronary or cervical infiltration.

Therefore, it is imperative to maintain the coronary seal during the time elapsed between the filling of the root canals and the making of the permanent restoration, since once it is exposed to the oral microbiota, it can compromise the success of endodontic therapy (Pisano et al., 1998).

Seixas et al. (2008) point out that coronary microleakage depends on two factors: the material / dental structure interface and the physical-chemical properties of restorative materials, such as solubility, disintegration, contraction, expansion, and adhesion.

Thus, the solubility, disintegration capacity, and dimensional instability (contraction and expansion) of the material compromise the maintenance of the coronary seal, contributing to the increase in the passage of microorganisms, toxins, and chemicals from the oral cavity to the interior of the dentinal tubules (Heleno, 2004).

Coronary infiltration, seen in vitro (Swanson and Madison, 1987; Madison et al., 1987; Torabinejad et al., 1990; Magura et al., 1991) has been linked to the failure of endodontic therapy (Saunders and Saunders, 1994; Ray and Trope, 1995), explaining, in a way, some situations in which, despite the careful execution of the treatment and the good radiographic quality of the fillings, the unexpected and undesirable success occurs.

Salazar-Silva et al. (2004) argue that the reviewed literature is unanimous in recognizing the importance of an adequate sealing of the root canal system for the success of endodontic therapy. In this context, marginal cervical sealing assumes an extremely important role, as it prevents the infiltration of oral fluids between sessions or after root canal filling, preventing bacterial recontamination and, consequently, decreasing the chances of a therapeutic failure (Torabinejad et al., 1990).

Ghisi \& Pacheco (2002) show that the importance of an adequate temporary restoration, of the endodontic access cavity, to prevent contamination of the root canal system through fluids and microorganisms is a consensus among the vast majority of authors (Bobots et al., 1989; Jacquot et al., 1996; Balto, 2002). However, there are several differences regarding the sealing properties of the various temporary restorative materials indicated for such procedures (Gekelman et al., 1999; Silveira et al., 2005; Travassos and Dias, 2005).

Among the materials found in the literature, used as a temporary restorative material, there are materials based on zinc oxide and eugenol reinforced with polymethyl methacrylate (MRI); materials based on zinc oxide, zinc sulfate, calcium sulfate, glycol acetate (cavit, coltosol, citodur, cimpat); resinous materials activated by visible light (Bioplic, TERM, Fermit); Glass Ionomer cement, divided into powder, containing silicon oxide (29\%), aluminum oxide (16.6\%), calcium fluoride (34.3\%), aluminum fluoride (7.3\%), fluoride sodium (3\%), aluminum phosphate $(9.8 \%)$ and liquid, whose chemical composition is based on $45 \%$ water, $30 \%$ polyacrylic acid, $15 \%$ itaconic acid and $10 \%$ tartaric acid. 
Zucco (2001) points out that the sealing effectiveness of temporary restorative materials used in the endodontic clinic can be tested and evaluated by different methods, such as radioisotopes, bacterial penetration (Torabinejad et al., 1990), thermocycling (Tamse et al., 1982; Lee et al., 1983; Kazemi et al., 1994), fluid filtration (Anderson et al., 1988; Pashley et al., 1988; Bobots et al., 1989) and electrochemical processes (Jacquot et al., 1996). However, the most used method uses dyes to identify the occurrence of infiltration (Swanson and Madison, 1987; Madison et al., 1987; Magura et al., 1991).

Several studies use the thermocycling methodology, simulating clinical conditions since the restorative materials are subjected to thermal changes in the oral cavity (Gekelman et al., 1999; Marques et al., 2005; Seixas et al., 2008).

Consistent with these observations, Gekelman et al. (1999) argue that a study that evaluates the sealing properties of these materials must reproduce this thermal stress, due to the possible dimensional instability of the restorations. However, the same authors admit that there are controversies in the literature regarding thermal change and the number of cycles to be used in thermal cycling. The minimum temperature used in several studies was, on average, $4^{\circ} \mathrm{C}$ and the maximum reached $60^{\circ} \mathrm{C}$. Some authors consider that the ideal extreme temperatures found in the oral cavity would be $5^{\circ} \mathrm{C}$ and $55^{\circ} \mathrm{C}$ (Lee et al., 1993; Uranga et al., 1999; Shinohara et al., 2004; Marques et al., 2005). The period of permanence of the samples for each thermal bath is also variable: 15 seconds (Travassos et al., 2002); 30 seconds (Heleno, 2000; Uranga et al., 1999; Ghisi and Pacheco, 2002); 60 seconds (Kazemi et al., 1994); 5 minutes (Shinohara et al., 2004); 120 minutes (Anderson et al., 1989). However, Tewari \& Tewari (2002) defend the non-use of thermocycling, as this causes significant dimensional changes in several materials, mainly in the MRI.

Critics of the use of dye attribute to its small molecular size, the greater capacity of penetration about saliva. Based on this premise, they consider that, although such results can be used for comparative effectiveness, the penetration of dyes, in reality, does not express the pattern of microbial infiltration that occurs in the clinical situation. As it does not provide data on the level of infiltration of larger particles or molecular aggregates, such as microorganisms and enzymes, this methodology does not reflect the real conditions for sealing the fillings, since the prognosis of an endodontic therapy depends on the infiltration of macromolecules (Zucco, 2001). Not always where the dye penetrates, there will be bacterial infiltration (Fachin et al., 2007).

In contrast to these observations, several authors state that the fact that the particle size of the dye is smaller than the microorganisms results in more accurate tests than the bacterial penetration (Travassos and Dias, 2005). If the dye identifies the microleakage, there is a pathway: bacteria or their by-products can pass in a greater or lesser time (Fachin et al., 2007). In addition, some temporary sealing materials exhibit bacteriostatic properties, that is, if there is infiltration, there will be no proliferation of microorganisms (Travassos and Dias, 2005). When measured directly, the penetration of the endotoxin is insignificant and penetrates the root canal less frequently and to a lesser extent than the dye (Marques et al., 2005).

Gekelman et al. (1999) point out that the use of dye in vitro allows quantitative measurement of the infiltration, in addition to allowing direct visual observation of the infiltration site and the tooth-restoration interface. Travassos \& Dias (2005) affirm that the methylene blue dye has a good infiltration marker, defined spots, good interpretation, obtaining, and reading. Holland et al. (1992 apud Ramos and Galan Jr., 2004) concluded that the procedure with vacuum and 2\% methylene blue was the one that best evaluated the existing infiltration between sealer material and tooth wall.

However, Silveira et al. (2005) and Seixas et al. (2008) used the histochemical methodology for disclosing coronary infiltration by the formation of the Nidimethylglioxima complex of nickel sulfate with dimethylglioxima alcohol. These authors list the advantages of this method: high sensitivity for the identification of nickel ions by dimethylglioxima; low molecular weight of nickel ions (58.69) compared to methylene blue dye (319.85) and rhodamine B dye (479); the size of nickel ions, which are as small as radioactive isotopes, but without risk of contamination; and, finally, ease of reading, since 
only at the point of contact between the nickel and dimethylglioxima ions, the reddish-colored Nidimethylglioxima complex forms.

The depth of the cavity that will receive the restorative material is another factor that deserves special attention, as the temporary sealing material must be thick enough to provide a correct sealing and prevent contamination through the sealing material (Ghisi and Pacheco, 2002). Webber et al. (1978) concluded that the thickness of the sealer must be at least $3.5 \mathrm{~mm}$; Tamse et al. (1982) used $5 \mathrm{~mm}$ in their investigations; Anderson et al. (1988) inserted $4 \mathrm{~mm}$; Sauáia (2000), $5 \mathrm{~mm}$ and Marques et al. (2005), $3.5 \mathrm{~mm}$.

Scientists have long been experimenting with new compositions of temporary sealing materials and different ways of using them to achieve the least marginal infiltration (Pecora et al., 2002). The studies by Fachin et al. (2007) corroborate the findings of Ghisi and Pacheco (2002), Shinohara et al. (2004), and Marques et al. (2005) when verifying the efficiency of Bioplic temporary restorative material, photopolymerizable material composed of BIS-GMA, silicon dioxide, dimethylcrylate groups, inorganic filler and photoactivator, which gives it the following advantages: reduced porosity and good adaptation cavity margins. There is a consensus between such research and the studies by Travassos and Dias (2005) and Seixas et al. (2008), who attributes the good performance to said material to its composition, based on composite resin and the viscosity in which it is presented. The aforementioned authors further argue that Bioplic is an aesthetic, practical material and does not require manipulation. However, Ghisi \& Pacheco (2002) reveal a deficiency in its insertion: despite using the spatula suitable for composite resin, moistened with alcohol, the material remained adhered to it, making it difficult to insert it into the cavity. Such authors recognize that, as it is a recent commercial launch, it is necessary to carry out studies using this material in daily clinical practice. Fachin et al. (2007) add that it is premature to indicate it as the first choice of provisional sealing material before other studies are carried out. It is important that other properties of the material, such as biocompatibility, dimensional stability, resistance to masticatory impact, and use in complex cavities, are evaluated for its correct indication.

Contrary to the studies described above, Mattos et al. (2003) concluded in their experiments, that Bioplic was inefficient as a temporary restorative material since it was unable to prevent coronary microleakage, being inferior to the other two materials tested: Tempit L / C, a provisional restorative cured in pre-cured tips dosed and Citodur (Hard), a provisional restorer that acquires prey with exposure to moisture.

Also concerned with experimenting with materials and techniques that would reduce coronary infiltration, Gekelman et al. (1999) concluded that the temporary restorative material Cimpat, a pre-mixed cement, especially used for endodontic use, promoted a good sealing in the occlusal portion, for one week, adapting to the requirements of a temporary endodontic seal between sessions treatment. Hygroscopic material similar to Cavit, has a large linear expansion, resulting from the absorption of water during its setting. However, these authors recognize that such material has low resistance to abrasion and compression, and is, therefore, contraindicated in large cavities that require greater effort to support masticatory forces. Such findings become more consistent when compared with the research by Tamse et al. (1982), Anderson et al. (1988), Kazemi et al. (1994), Pisano et al. (1998). However, Ghisi \& Pacheco (2002) claim that the material, despite being easy to insert, leaves residues and hinders the final restoration, which could contraindicate it in cases where the temporary restoration will remain for a short time. Uçtash \& Tinaz (2000), on the other hand, contraindicate cement that presents zinc oxide without eugenol only when aesthetics is an important factor and there is little remaining dental structure, due to non-adherence to the dentinal walls.

Carvalho et al. (2005) evaluated the efficiency of Cimpat, Glass Ionomer cement, and zinc oxide and eugenol, combined in double sealing, and concluded that the samples sealed by Cimpat associated with zinc oxide and eugenol obtained the best microbial sealing results. Such fact could constitute an alternative to the single-layer sealing, aiming to improve the 
sealing. This concept has already been developed by Magura et al. (1991) who suggested the use of double layers, placing a good sealer underneath, such as moisture-hardened cement and the most resistant one, based on zinc oxide and eugenol.

However, Webber et al. (1978) argue that double sealing does not affect the quality of the sealing of temporary restorative materials. They list variables that can cause infiltration in the temporary restoration: inadequate preparation of cavity access that can cause fractures of the enamel walls and produce marginal cracks. Poor adaptation of cavity walls, debris between walls, and restoration can also lead to marginal sealing failures. Using similar methodological resources, Marques et al. (2005) and Silveira et al. (2005), evaluated results regarding coronary sealing and emphasized the good performance of Coltosol, directly related to the absorption of natural moisture present in the oral cavity, a property possibly due to the presence of calcium sulfate in its formula. However, in the studies by Silveira et al. (2005), the increase in infiltration seen with Coltosol over time probably can be justified by the longer immersion in the dye solution, which would facilitate its penetration into the temporary restorative tooth-material interface, a finding also verified in others studies.

Uçtash \& Tinaz (2000) argue that the presence of calcium sulfate in the formulation of coltosol may indicate that this substrate is responsible for the action of the prey. Theoretically, the reasoning that an expansion/expansion would be necessary makes sense to reduce or even cancel the microleakage, but one fact attracts attention when late expansions are observed, which can cause a temporary cement to almost double in size. In this sense, from a clinical point of view, it is important to note that, in some cases, the occurrence of fractures can be observed, depending on the thickness of the remaining walls, in addition to the appearance of premature contacts and occlusal trauma. In agreement with the referred authors, Liberman et al. (2001) demonstrated that the use of materials derived from calcium sulfate should be limited to areas not subjected to occlusal loads, as in dental elements that do not have antagonists. In other cases, the use of these materials can lead to loss of the seal, due to the application of repetitive occlusal forces that can cause fatigue of the material.

The results of the research by Marques et al. (2005) differ from the investigations carried out by Ramos and Galan Jr (2004) and Sauáia (2006). Marques et al. (2005) concluded that the composite resin and the glass ionomer cement are not effective in minimizing coronary infiltration and admit that this divergence probably occurred due to the methodological variations employed, mainly with the selection of the teeth, the thermocycling cycles used, and the use of composite resin, glass ionomer cement without the necessary technical requirements, since there was in the endodontic access cavity, a sterile cotton ball containing the intracanal medication. The previous acid conditioning and the adhesive system were not carried out in the case of composite resins, nor the necessary conditioning for the use of Glass Ionomer cement.

Balto (2002) investigated the microbial infiltration of Dyract, Cavit, and MRI and confirmed that Dyract and Cavit provided a more efficient seal than MRI. The good sealing ability of Dyract can be attributed to the fact that it contains filling adhesives, which are believed to reduce polymerization shrinkage and provide marginal integrity, which is consistent with the findings of Uranga et al. (1999), who attribute the choice of Dyract in their studies to adhesiveness and the fact that it is considered a permanent restorative material. Cavit's efficiency can be attributed to its relatively high linear expansion during placement, which is in agreement with the studies by Chohayeb and Bassiouny (1985); Anderson et al. (1988) Bobots et al. (1989), and Lee et al. (1993). On the other hand, the hydrophilic capacity can provide infiltration through the material itself (Tamse et al., 1982).

Balto (2002) attributed the poor sealing ability of the MRI to the fact that powder and liquid have to be mixed to produce the paste, which would cause a reduction in inhomogeneity. This conclusion is consistent with the findings of Ghisi and Pacheco (2002) and Silveira et al. (2005), which justify the low performance of the MRI, citing several factors: thermal cycling causes significant dimensional changes in temporary restorative materials, especially the MRI; contractions during prey; reduced adhesion to the dental structure and greater sensitivity of the technique for handling and insertion of the material, since the powder / liquid ratio of $6 \mathrm{~g} / 1 \mathrm{ml}$ in weight, recommended by the manufacturer, allows us to spatulate the mixture for 
1 minute, resulting in a very rigid consistency, which makes its application difficult. For this reason, some researchers such as Anderson et al. (1988) realized that restorations made with MRI tend to detach from dental walls more easily after being sectioned.

Cavit and TERM, on the other hand, did not move from the walls, even after being gently manipulated with a spoon of dentin. They attributed the precarious sealing of the MRI in endodontic accesses after thermal stress to its dimensional instability, which is consistent with the studies by Bobots et al. (1989), thus justifying the change in the powder-liquid ratio, from $6 \mathrm{~g} / 1 \mathrm{ml}$ in weight, recommended by the manufacturer, to $4 \mathrm{~g} / \mathrm{ml}$, as he believes that this proportion provided the best seal for that material. Lee et al. (1993) changed the powder / liquid ratio of the MRI to verify variations in the sealing capacity of the material. The proportion of $2 \mathrm{~g} / \mathrm{ml}$ demonstrated a better performance to coronary microleakage than the proportion suggested by the manufacturer. But studies are needed to identify the effects of these changes on the abrasion resistance properties of the material. Tamse et al. (1982) mention that free eugenol reacts chemically with the dye, saturating it and preventing its entry into the material, causing the dye to infiltrate only at the tooth-restoration interface.

Contrary to several studies reported in the literature, Liberman et al. (2001) concluded that the performance of material testing for microleakage without reference to masticatory forces must have limited value, as they do not reliably reproduce the clinical situation found in the oral cavity. Then, they suggest the indication of MRI in places that require greater occlusal strength.

The results of research by Travassos \& Dias (2005) are in line with the findings of Sauáia (2000) to Vitremer, which presented undesirable performance, probably due to the polymerization contraction and the difference in the thermal expansion coefficient between the tooth structure and the modified ionomer. This could have caused an inadequate adhesion to the cavity walls or the rupture of the union at the tooth-restoration interface, caused by eventual dehydration with consequent microleakage. Such observations contradict the studies by Bobots et al. (1989) and Ramos and Galan Jr (2004), who used a resin-modified glass ionomer cement (Fuji II) and obtained a coronary seal as effective as Cavit when using a fluid filtration and thermal cycling technique. In the experiments by Bobots et al. (1989), the teeth were stored in a humid environment, which faithfully reproduces the clinical reality, that is, the temporary restorative material is exposed to saliva soon after its insertion. This provides a faster hygroscopic expansion, which contributes to a better seal.

Regarding the performance of Flow composite resin and Z100 resin, Sauáia (2000) attributed the best results obtained with Z100 resin to the use of the incremental technique for photopolymerizable compounds. Thus, the Z100 resin was placed in an increment at the entrance of the root canal, and then the layers were arranged obliquely, to maintain the maximum free surfaces of the material, to reduce the contraction during polymerization. This form of insertion did not occur with the Flow resin, because due to its viscosity, the flow did not provide this behavior of the material, making the insertion in horizontal increments. Its contraction, due to polymerization, has been identified as one of the factors directly responsible for marginal infiltration at the tooth-restoration interface. Since the coefficient of thermal expansion of the tooth and the composite resin is different, thermocycling probably caused the rupture of the marginal seal, with consequent infiltration into the space caused by the polymerization contraction.

Zucco (2001) considers that the occurrence of microbial infiltration, in isolation, does not determine the installation and/or maintenance of periapical lesions, which would configure the failure of endodontic therapy. Success is the sum of several aspects, one of which is the obtaining and preservation of the root canal filling.

The present study confirms the importance of choosing materials capable of sealing the coronary cavity after endodontic treatment, to avoid bacterial contamination and improve the prognosis of the intervention. However, it can be said that the ideal provisional sealing material, which has all the favorable characteristics of use and no coronary infiltration, has not yet been obtained. Thus, it is up to the researchers to develop clinical studies and the manufacturers to develop more 
effective materials that present superior adaptation to the cavity walls, with lower or even null indexes of marginal coronary infiltration.

\section{Conclusion}

Scientific evidence allows us to conclude that the correct filling of the root canal system and the improved restoration of the dental element prevent bacterial proliferation and recontamination and that microleakage due to the lack of coronary seal is a factor of great concern in the endodontic clinic. Following this principle, the need for the use of a good temporary sealer is indisputable. The dental market has numerous restorative materials used for this purpose, with variable sealing capacity. Some have better resistance to the forces of mastication (MRI); others have a better sealing ability (Cavit, Coltosol).

Thus, numerous studies have been evaluating cervical microleakage, looking for a material that presents adequate resistance and sealing capacity. There is a consensus among several authors that the thickness of the material must be at least $3.5 \mathrm{~mm}$ to provide an effective seal and that the endodontically treated teeth exposed to saliva present infiltration soon after the 3rd day.

Therefore, the definitive restoration of the dental element immediately after the endodontic treatment is completed is of vital importance for a good prognosis. The success of endodontic therapy does not depend only on a chemical-mechanical preparation, but on the combination of careful endodontic treatment and a well-designed coronary restoration.

\section{References}

Allison, D. D., Weber, C. R., \& Walton, R. E. (2001). The influence of the method of canal preparation on the quality of apical and coronal obturation. J Endod. 1979; 5(10): 289-304 apud Zucco LR. Avaliação da infiltração coronária em canais obturados e preparados para pino. [Monografia]. Canoas: Universidade Luterana do Brasil.

Anderson, R. W., Powell, B. J., \& Pashley, D. H. (1988). Microleakage of three temporary endodontics. J Endod. 14(10): 497-501.

Balto, H. (2002). An assessment of microbial coronal leakage of temporary filling materials in endodontically treated teeth. $J$ Endod. $28(11): 768-764$.

Barbosa, H. G., Holland, R., \& Souza, V. (2003). Infiltração marginal coronária em canais radiculares após prepare para pino: influência do tipo de cimento obturador e de um plug de cimento temporário. JBE. 4(14): 208-212.

Barthel, C. R., Strobach, A., Briedigkeit, H., Göbel, V. B., \& Roulet, J. F. (1999). Leakage in roots coronally sealed with different temporary fillings. J Endod. 25(11): 731-734.

Barthel, C. R., Zimmer, S., Wussogk, R., \& Roulet, J. F. (2001). Long-term bacterial leakage along obturated roots restored with temporary and adhesive fillings. J Endod. 27(9): 559-561.

Bobots, H. G., Anderson, R. W., \& Pashley, D. H. (1989). A microleakage study of temporary restorative materials used in endodontics. J Endod. 15(12): 569572 .

Carman, J. E., Wallace, J. A. (1994). An in vitro comparison of microleakage of restorative materials in the pulp chambers of human molar teeth. J Endod. 20(12): 571-575.

Carvalho, G. L., Habitante, S. M., Jorge, A. O. C., \& Marques, J. L. L. (2003). Cimentos provisórios utilizados no selamento entre sessões do tratamento endodôntico - estudo microbiológico. JBE. 4(15): 297-300.

Celik, E. U., Yapar, A. G. D., Ates, M., \& Sem, B. H. (2006). Bacterial microleakage of barrier materials in obyturated roots canals. J Endod. 32(11): 10741076 .

Chohayeb, A. A., \& Bassiouny, M. A. (1985). Sealing ability of intermediate restorative used in endodontics. J Endod. 11(6): 241-244.

Crim, G. A., \& Mattingly, S. L. (1981). Evaluation of two methods for assessing marginal leakage. The Journal of Prosthetic Dentistry. $45(2)$ : $160-163$.

Deus, Q. D. (1992). Endodontia. $5^{\text {a }}$ Ed. Rio de Janeiro: Medsi; p. 444.

Fachin, E. V. F., Perondi, M., \& Grecca, F. S. (2007). Comparação da capacidade de selamento de diferentes materiais restauradores provisórios. RPG Rev Pós Grad. 13(4): 292-298. 
Galvan, R. R., West, L. A., Liewehr, F. R., \& Pashley, D. H. (2002). Coronal microleakage of five materials used to create an intracoronal seal in endodontically treated teeth. J Endod. 28(2): 59-61.

Gekelman, D., Deonízio, M. D. A., Prokopowistsch, I., \& Gavini, G. (1999). Microinfiltracão de quatro selamentos endodônticos provisórios após a termociclagem. ECLER Endod.1(1).

Ghisi, A. C., \& Pacheco, J. F. M. (2002). Estudo in vitro da microinfiltração coronária em materiais restauradores temporários usados em Endodontia. Revista Odonto Ciência. 17(35): 62-70 apud.

Grossman, L. I. (2002). A study of temporary filling as hermetic sealing agents. J Dent Res. 1939; 2(18): 67-71 apud Pecora JD, Seixas FH, Capelli A, Barbin EL, Spano JCE. Materiais obturadores provisórios [Dissertação]. Ribeirão Preto: Universidade de São Paulo.

Haapasolo, M., Udnæs, T., \& Endal, U. (2003). Persistent, recurrent and acquired infection of the root canal system post - treatment. Endodontic Topics. 6: $29-56$.

Heleno, J. F. G. (2004). Análise comparativa da capacidade marcadora de infiltração marginal de três corantes [Dissertação]. Belo Horizonte: PUC.

Hizatugu, R., Kado, E., Miyasaki, E., Okino, K., Meneguine, G. P., \& Matayoshi, A. (2002). Endodontia em sessão única. Mito ou realidade? São Paulo: Atheneu; p. 33.

Holland, R. et al. (2004). Avaliação da infiltração marginal de materiais seladores temporários - influência do emprego a vácuo. RGO. 1992; 40(1): 29-32 apud Ramos AA, Galan Jr J. Infiltração marginal de cimentos provisórios em dentes tratados endodonticamente. RGO. 52(4): 305-308.

Holland, R., Sakashita, M. S., Murata, S. S., \& Júnior, E. D. (1995). Effect of dentine surface treatment on leakage of root fillings with a glass ionomer sealer. Int Endod J. 28: 190-193.

Jacquot, B. M., Panighi, M. M., Steinmetz, P., \& Sell, C. G. (1996). Microleakage of Cavit, Cavit W, Cavit G and IRM by impedance spectroscopy. Int Endod J. 29: 256-261.

Kazemi, R. B., Safavi, K. E., \& Spangberg, L. S. W. (1994). Assessment of marginal stability and permeability of an interim restorative endodontic material. Oral Surgery Oral Medicine Oral Pathology. 78: 788-796.

Lacerda, M. R. \& Costenaro, R. G. S. (2017). Metodologias da pesquisa para a enfermagem e saúde. Editora Moriá (livro atualizado), 1(5): 123.

Lee, Y. C., Yang, S. F., Hwang, Y. F., Chueh, L. H., \& Chung, K. H. (1993). Microleakage of endodontics temporary restorative materials. J Endod. 19(10): 516-520.

Liberman, R., Ben-Amar, A., Frayberg, E., Abramovitz, I., \& Metzger, Z. (2001). Effect of repeated vertical loads on microleakage of IRM and Calcium Sulfate-Based temporary fillings. J Endod. 27(12): 724-728.

Madison, S., Swanson, K., \& Chiles, S. A. (1987). An evaluation of coronal microleakage in endodontically treated teeth. Part II. Sealer types. 13(3): 109-112.

Madison, S., \& Wilcox, L. R. (1988). An Evaluation of coronal microleakage in endodontically treated teeth. Part III. In vivo study. J Endod. 13(3): 109-112.

Magura, M. E., Kafrawy, A. H., Brown, C. E., \& Newton, C. W. (1991). Human saliva coronal microleakagein obturated root canals: in vitro study. J Endod. 17(7): 324-329.

Marques, M. C. O. A., Paiva, T. P. F., Soares, S., \& Aguiar, C. M. (2005). Avaliação da infiltração marginal em materiais restauradores temporários - um estudo in vitro. Pesq Bras Odontoped Clin Integr. 5(1): 47-52.

Mattos, N. H. R., Júnior, A. C. P., \& Melo, L. L. (2003). Análise da infiltração coronária em três tipos de restauradores provisórios de uso em Endodontia. JBE. 4(13): 153-158.

Mayer, T., \& Erickholz, P. (1997). Microleakage of temporary restorations after thermocycling and mechanical loading. J Endod. 33(5): 320-322.

Oliveira, E. C. G. et al. (2005). Estudo in vitro da infiltração marginal de alguns materiais restauradores provisórios avaliados através de ciclagem térmica. Rev Fac Odontol. Lins. 17(1): 33-38.

Pashley, D. H. (1990). Clinical considerations of microleakage. J Endod. 16(2): 70-75.

Pecora, J. D., Seixas, F. H., Capelli, A., Barbin, E. L., \& Spano, J. C. E. (2002). Materiais obturadores provisórios [Dissertação]. Ribeirão Preto: Universidade de São Paulo.

Pisano, D. M., DiFiore, P. M., McClanahan, S. B., \& Lautenschlager, E. P. (1988). Intraorifice sealing of gutta-percha obturated roots canals to prevent coronal microleakage. J Endod. 24(10): 659-662.

Ramos, A. A., \& Galan Jr, J. (2004). Infiltração marginal de cimentos provisórios em dentes tratados endodonticamente. RGO. 52(4): 305-308.

Ray, H. A., \& Trope, M. (1995). Periapical status of endodontically treated teeth in relation to the technical quality of the root filling and the coronal restoration. Int Endod J. 28:12-18.

Reiss-Araújo et al. (2005). Análise da ação antimicrobiana de materiais seladores provisórios coronários utilizados em endodontia. Revista Sul-Brasileira de Endodontia. 8-14.

Salazar-Silva, J. R., Pereira, R. C. S., \& Ramalho, L. M. P. (2004). Importância do selamento provisório no sucesso do tratamento endodôntico. Pesq Bras Odontoped Clin Integr. 4(2): 143-149. 
Research, Society and Development, v. 10, n. 6, e22210615584, 2021

(CC BY 4.0) | ISSN 2525-3409 | DOI: http://dx.doi.org/10.33448/rsd-v10i6.15584

Sauáia, T. S. (2000). Avaliação in vitro da resistência da infiltração marginal de quatro materiais utilizados no selamento coronário em dentes tratados endodonticamente [Dissertação]. Piracicaba: Universidade Estadual de Campinas.

Seixas, F. H., Martinelli, D. F., Cecchin, D., Ribeiro, R. G., Silva, R. S., \& Pecora, J. D. (2008). Avaliação ex vivo da microinfiltração marginal coronária de restauradores provisórios usados em endodontia. RFO UPF. 13(3): 31-35.

Shinohara, A. L., Oliveira, E. C. G., Duarte, M. A. H., Yamashita, J. C., Kuga, M. C., \& Fraga, S. C. (2004). Avaliação in vitro da infiltração marginal de alguns materiais seladores provisórios submetidos à ciclagem térmica. JBE. 5(16): 79-85.

Silveira, G. A. B., Nunes, E., \& Silveira, F. F. (2005). Infiltração marginal de dois seladores provisórios em diferentes tempos. Arquivos em Odontologia. 41(2): 105-192.

Siqueira, J. F., \& Rôças, I. N. (2008). Clinical implications and microbiology of bacterial persistence after treatment procedures. J Endod. 34(11): 1291-1301.

Soares, J. A. (2004). Microbiota dos canais radiculares associada às lesões periapicais crônicas e sua significância clínica. JBE. 5(16): 79-85.

Swanson, K., \& Madison, S. (1987). An evaluation of coronal microleakage in endodontically treated teeth. Part I. Time periods. J Endod. $13(2): 56-59$.

Tamse, A., Ben-Amar, A., \& Gover, A. (1982). Sealing properties of temporary fillings materials used in endodontics. J Endod. 8(7): 322-325.

Tewari, S., \& Tewari, S. (2002). Assessmet of coronal microleakage in intermediately restored endodontic acess cavities. Oral Surgery Oral Medicine Oral Pathology. 93: 716-719.

Torabinejad, M., Ung, B., \& Kettering, J. D. (1990). In vitro bacterial penetration of coronally unsealed endodontically treated teeth. Endodontic Dent Traumatol.16(12): 566-569.

Uçtash, M. B., \& Tinaz, A. C. (2000). Microleakage of different types of temporary restorative materials used in endodontics. Journal of Oral Science. 42(2): 63-67.

Uranga, A., Blum JY., Esler S., Parahy E., \& Prado C. (1999). A comparative study of four coronal obturation materials in endodontic treatment. $J$ Endod. 25(3): 178-180.

Webber, R. T., Del Rio, C. E., Brady, J. M., \& Segall, R. O. (1978). Sealing quality of a temporary filling material. Oral Surg. 46(1):123-130.

Wells, J. D., Pashley, D. H., Loushine, R. J., Weller, R. N., Kimbrough, F., \& Pereira, P. N. (2002). Intracoronal sealing ability of two dental cements. $J$ Endod. 28(6): 443-447.

Wolanek, G. A., Loushine, R. J., Weller, R. N., Kimbrought, W. F., \& Volkmann, K. R. (2001). In vitro bacterial penetration of endodotically treated teeth coroally sealed with a dentin bonding agent. J Endod. 27(5): 353-357.

Zucco, L. R. (2001). Avaliação da infiltração coronária em canais obturados e preparados para pino. [Monografia]. Canoas: Universidade Luterana do Brasil. 